\title{
PROSPECTS FOR THE USE OF PLASMA SPRAYING IN MEDICINE
}

\author{
Institute of Technical Mechanics \\ of the National Academy of Sciences of Ukraine and the State Space Agency of Ukraine, 15 Leshko-Popel St., \\ Dnipro 49005, Ukraine; e-mail: novyje@ex.ua
}

The aim of this paper is to analyze the experience in and the prospects for using plasma spraying in the solution of medicine-related problems.

The main lines in the medical use of plasma spraying are dental implant making and bone and joint prosthesis making.

The metal implant - bone tissue system is the most complex composite material formed in the human body. The paper analyzes the factors that must be considered for the successful making of implants intended for a longterm use in the patient's body. The main materials that are currently used in their making are titanium and its alloys (they are applied to the metal parts of prostheses to increase their wear resistance), hydroxyapatite (HA), and fluorite (they have a structure similar to the bone tissue, as a result of which the prostheses are not rejected and grow into the bone).

The paper presents practical results of the use of plasma spraying in prosthesis making and the features of implant surface formation. The aspects of porous structure "osteojunction" (the ability of the material to promote the growth of the bone tissue deep into and along the implant) and osteointroduction (an additional capability of the structure and the behavior of the newly formed bone tissue at the local level) are discussed. Ideas of the surface structure of implants best suited to their integration with the bone tissue are outlined.

The results of the diagnostic methods currently used in biomedical research to control the quality of prostheses made using plasma spraying are presented.

The general conclusion of the analysis of the achievements in the use of plasma spraying in prosthesis making is as follows: the density of filling of the porous layer on the implant surface with the newly formed bone tissue and the strength of that bone tissue determine the efficiency of implant-to-bone load transfer, the mechanical strength of the resulting composite material, and the implant durability. This statement is a result assessment criterion in the course of further improvement of plasma spraying for medical purposes.

Keyords plasma spraying, prosthesis making, dental implant making, material structure study, strength control methods, biocompatibility, biological tissue study methods.

1. Hench L.L. Bioactive materials: The potential for tissue regeneration. J. Biomat. Mater. Res. 1998. V. 41, No. 4. Pp. 511-518.

2. Kitsugi . Bone-bonding behavior of plasma sprayed coatings of bioglass RAW-glass ceramic, and tricalcium phosphate in titanium alloy. J. Biomed. Mater. Res. 1996. V. 30, No. 2. P. 261.

3. Schrooten J., Van Oosterwyck H., Sloten J. Vander, Helsen J. A. Adhesion of new bioactive glass coating. J. Biomed. Mater. Res. 1999. V. 44, No. 3. Pp. 243-252.

4. Klein C. P. Calcium phosphate sprayed coatings and their stability: An in vivo study. J. Biomed. Mater. Res. 1994. V. 28, No. 8. Pp. 909-917.

5. Khor K. A., Cheang P. Effect of powder feedstock on thermal sprayed hydroxyapatite coatings. Proc. $7^{\text {th }}$ Nat. Thermal. Spray Conf. 20-24 June 1994, Boston, Massachusetts. 1994. Pp. 147-152.

6. Gomez-Vega L. M., Saiz E. Glass-based coatings for titanium implant alloys. J. Biomed. Mater. Res. 1999. V. 46, No. 4. Pp. 549-559.

7. Weng $J$. Integrity and thermal decomposition of apatits in coatings influenced by underlying titanium during plasma spraying and post-heat treatment. J. Biomed. Mater. Res. 1996. V. 30, No. 5. P. 5.

8. Loesberg W. A., Walboomers X. F., Van Loon J. J., Jansen J. A. The effect of combined cyclic mechanical stretching and microgrooved surface topography on the behavior of fibroblasts. J. Biomed. Mater. Res. 2005. V. 75A. Pp. $723-732$.

9. Harris H. Overview of problems surrounding the plasma spraying of hydroxyapatite coatings (Invited Paper). Thermal Spray Research and Applications Proceedings the Third National Thermal Spray Conference, Long Beach, CA, USA, 20-25 May 1990. 1990. Pp. 419-423.

10. Borsari V., Giavaresi G., Fini M., Torricelli P., Salito A., Chiesa R., Chiusoli L., Volpert A., Rimondini L., Giardino $R$. Physical characterization of different roughness titanium surfaces, with and without hydroxyapatite coating, and their effect on human osteoblast-like cells. J. Biomed. Mater. Res. Part B: Appl. Biomater. 2005. V. 75B. Pp. 359-368.

11. Tong $W$. Effect of particle size on molten states of starting powder and degradation of relevant plasma-strayed hydroxyapatite coatings. Biomaterials. 1996. V. 17. No. 15. Pp. 1507-1514.

12. Kalita V. I., Komlev D. I. Plasma Coatings with Nanocrystall and Amorphous Structure (in Russian). Moscow: Lider M, 2008. 388 pp. 
13. Strogonova E. E., Mikhaylichenko N. Yu., Sarkisov P. D., Kalita V. I. Potassium phosphate bioactive glass ceramic coatings (in Russian). Proc. XIX ${ }^{\text {th }}$ All-Russian Conference on Temperature-Resistant Functional Coatings. St. Petersburg, Russia, 15-17 April 2003. St. Petersburg: Yanus, 2003. Pp. 127-131.

14. Hing K. A., Best S. M., Tanner K. E., Bonfield W., Revell P. A. Mediation of bone ingrowth in porous hydroxyapatite bone graft substitutes. J. Biomed. Mater. Res. 2004. V. 68A. Pp. 187- 200.

15. Sevast'yanov V.I. New generation of materials for medicine (in Russian). Perspekt. Mater. 1997. No. 4. Pp. 56-60.

16. Santis D. Adult human bone cells from jaw bones cultured on plasma-sprayed or polished surfaces of titanium or hydroxylapatite discs. J. Mater. Sci. Mater. Med. 1996. V. 7, No. 1. Pp. 21-28.

17. Klimenov V. A. et al. Structure and phase composition of plasma-sprayed apatite coatings on implants (in Russian). Perspekt. Mater. 1997. No. 5. Pp. 44-49.

18. Gross. K. A. Identification and mapping of the amorphous phase in plasma-sprayed hydroxyapatite coatings using scanning cathodoluminescence microscopy. J. Mater. Sci. Mater. Med. 1998. V. 9, No. 12. Pp. $797-802$.

19. Girardin E. Characterization techniques for hydroxyapatite deposited by plasma spray on hip prosthesis. Mater. \& Manuf. Processes.1998. V. 13, No. 4. Pp. 581-588.

20. Cimdins R. Gemeinschaftssymposium der Klinik und Poliklinik fur Mund-,Kiefer-,und Plastische Gesichtschirurgie der Lettischen Medizinischen Fakultat der Universitat Rostock, Riga, 1995 und Rostock, 1998. Rostock. Med. Beitr. 1999. No. 8. Pp. 281-285.

21. Polzonetti G. Surface reactions of a plasma-sprayed CaO-P[2]O[5]-SiO[2]-based glass with albumin, fibroblasts and granulocytes studied by XPS, fluorescence and chemiluminescence. Biomaterials. 2000. V. 21, No. 15. Pp. 1531-1539.

22. Cizek J., Matejicek J. Medicine meets thermal spray technology: A review of patents. J. Therm. Spray Tech. 2018. V. 27. Pp. 1251-1279.

23. Ning C., Zhou L., Tan G. Fourth-generation biomedical materials. Mater. Today. 2016. V. 19(1). Pp. 2-3.

24. Heimann R. B. Plasma-sprayed hydroxylapatite-based coatings: chemical, mechanical, icrostructural, and biomedical properties. J. Therm. Spray Technol. 2016. V. 25, No. 5. Pp. 827-850.

Received on March 14, 2019, in final form on September 17, 2019 